 \\ International Journal of Social Sciences and Management
}

\section{A Rapid Publishing Journal}

ISSN 2091-2986

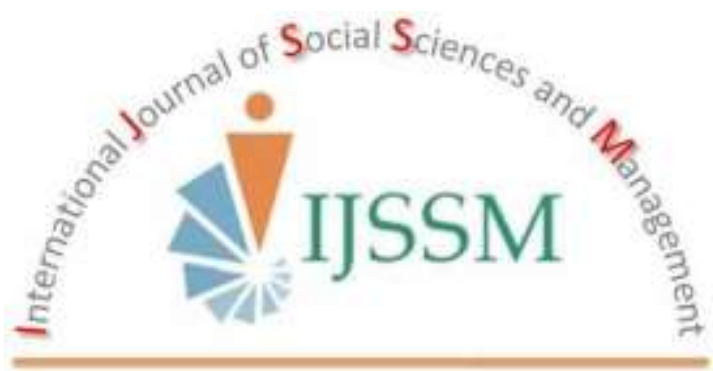

\section{Indexing and Abstracting}

CrossRef, Google Scholar, International Society of Universal Research in Sciences (EyeSource), Journal TOCs, New Jour, Scientific Indexing Services, InfoBase Index, Open Academic Journals Index (OAJI), Scholarsteer, Jour Informatics, Directory of Research Journals Indexing (DRJI), International Society for Research Activity (ISRA): Journal Impact Factor (JIF), Simon Fraser University Library, etc.

Vol-2(1) July, 2015 


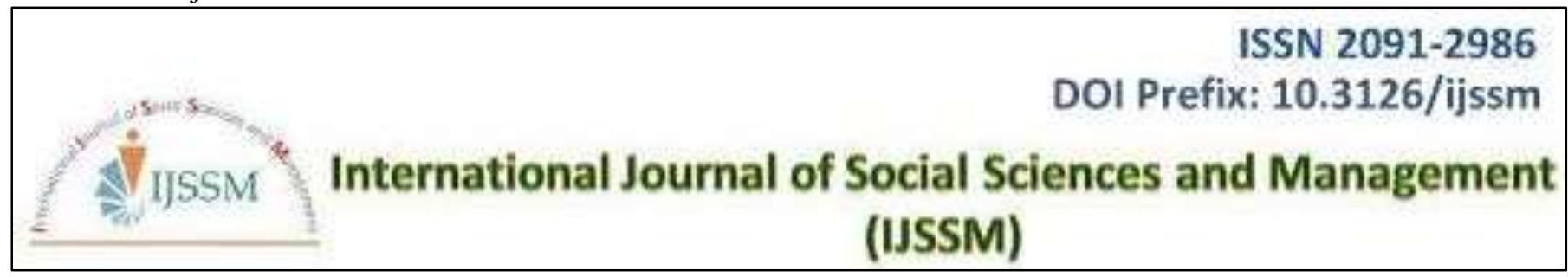

Research Article

\title{
IMPACT OF LIFE SKILLS ON LEADERSHIP DEVELOPMENT
}

\author{
Kriti Vashishtha \\ Manipal University, Jaipur, India \\ Email: vashishthakriti@gmail.com
}

\begin{abstract}
Life skills are basically the psychosocial skills which include personal, social, interpersonal, cognitive and affective components on an individual. For a better life one needs to have better decision making and problem solving skills. If any head or leader posses these characteristics then his/her tasks of making his/her leadership effective also becomes easy. Present study aims to see the impact of life skills sessions on problem solving and decision making attitude of school level leaders. For this purpose, 150 students were selected from 10 different schools. The age group ranged between 16-18 years. It is a pre and post test study. After taking the pre-test of the students (head/leaders) on the basis life-skills questionnaire by NCERT, the students were provided with 10 life-skills sessions ( 5 on problem solving and 5 on decision making, one session per day). After the sessions, the same questionnaire was administered on the students. On the basis of students' response, t-test was applied and results have showed a significant enhancement in the skills of decision making and problem solving in the leaders.
\end{abstract}

Keywords: life-skills; problem solving; decision making. Leaders.

\section{Introduction}

World Health Organization (1997) defines Life Skills, "as abilities for adaptive and positive behaviour that enable individuals to deal effectively with the demands and challenges of everyday life." Life-skills program has become a very important at school level (Gagne, 1974, 1984; Stice, 1987). The upcoming generation needs to have strong base of all the life-skills to have a better personality and secured future. Two of the major life-skills are problem solving and decision making. Decision making helps us to deal constructively with decisions about our lives. This can have consequences for health if young people actively make decisions about their actions in relations to health by assessing the different options, and what effects different decisions may have. Similarly, problem solving enables us to deal effectively with problems in our lives. Significant problems that are left unresolved can cause mental stress and give rise to accompanying physical strain. Both decision making and problem solving includes atleast four phases to be most effective (Dewey, 1933; Polya, 1971). Both of these are major characteristics of an effective leader. If the leader of a group possesses these characteristics then it becomes easy to achieve any goal or even to take failure gracefully. Leadership is an not an easy task, the school level leaders generally face the responsibilities of a group leader for the first time. This is just the beginning for them; if they are trained with certain skills then they stand up being better leaders then and later in life.

\section{Hypothesis}

It is hypothised that life-skills sessions will help leader to have better problem solving and decision making skills.

\section{Methodology}

The present paper studies the impact of life-skills on leadership development. It has been hypothised that lifeskills session will improve the decision making and problem solving skills in leaders. For this purpose, 150 school leaders from 10 different schools of Jaipur (Rajasthan) were selected. It is a pre and post test study. After taking the pre-test of the students (head/leaders) on the basis life-skills questionnaire by NCERT, the students were provided with 10 life-skills sessions (5 on problem solving and 5 on decision making, one session per day). After the sessions, the same questionnaire was administered on the students. On the basis of subjects' response the tscore was calculated.

\section{Results and Discussion}

The present paper studies the impact of life-skills on leadership development. It has been hypothised that lifeskills session will improve the decision making and problem solving skills in leaders. Table 1 shows the mean, $\mathrm{SD}, \mathrm{t}$ score and $\mathrm{p}$ value of the student leaders on decision making and problem solving skills (pre and post test). 
Table 1: Showing the Mean, SD, $\mathrm{t}$ score and $\mathrm{p}$ value for decision making and problem solving of pre and post test.

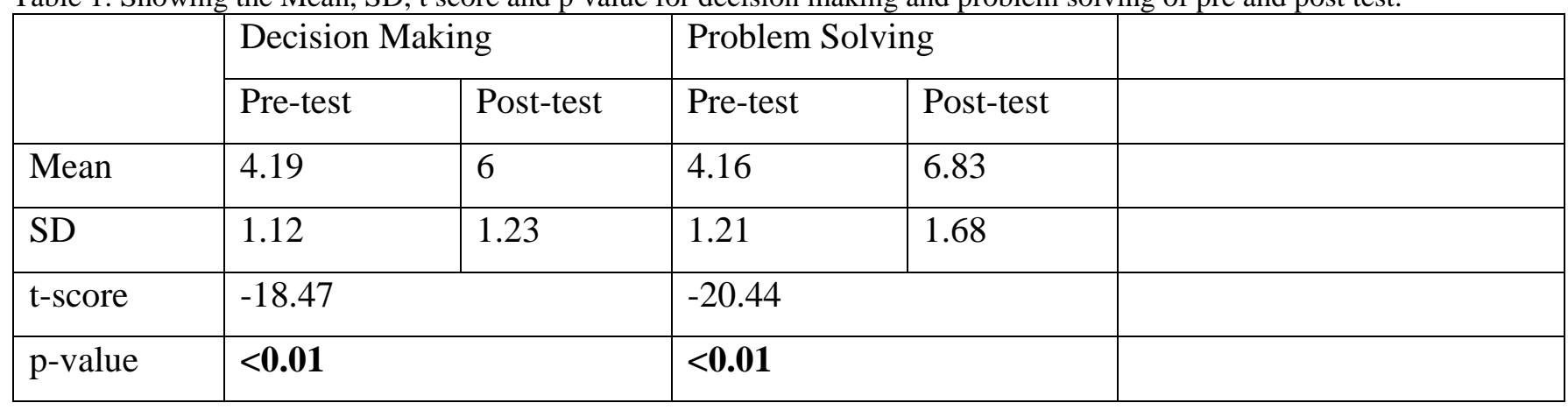

It can be seen that for decision making the mean values of pre and post test are 4.19 and 6 respectively. And, t-score is -18.47. Similarly, on problem solving, the mean values for pre and post test are 4.16 and 6.83 respectively. And, t-score is -20.44 . The high level of mean difference can be seen in both the cases. There is a significant difference in pre and post survey. In other words, the life-skills session did have impact on decision making and problem solving leadership skills. The above result table shows that earlier the leaders did not have much hand on the decision making and problem solving skills but after the life skills sessions, there has been a significant improvement in both the skills. The life skills sessions have helped the leaders to improve their personality, it has made them confident of taking decision for their team as well as to solve any particular problem with ease. They became better in analyzing, planning, categorizing and evaluating situations (Bloom et al., 1956; Sternberg, 1988), it has also helped them in making their thinking creative, lateral and divergent (Prince, 1970; Wonder and Donovan, 1984)

\section{References}

Bloom B, Englehart M, Furst E, Hill W and Krathwohl D (1956) Taxonomy of educational objectives: The classification of educational goals. Handbook I: Cognitive domain. New York: Longmans Green.

Gagne R. (1974) Essentials of learning from instruction. Hinsdale, IL: Dryden.

Gagne R (1984) Learning outcomes and their effects. American Psychologist 39: 377-385.

Dewey J (1933) How we think. New York: Heath. (Originally published in 1910).

Polya G (1971) How to solve it. Princeton, NJ: Princeton University Press. (Originally published in 1957).

Prince G (1970). The practice of creativity. New York: Macmillan.

Sternberg R (1988) The triarchic mind: A new theory of human intelligence. New York: Penguin Books.

Stice J (1987) Developing critical thinking and problem-solving abilities. San Francisco: Jossey-Bass.

Wonder J and Donovan P (1984) Whole-brain thinking: Working from both sides of the brain to achieve peak job performance. New York: Ballantine Books.

World Health Organization. (1997) Life skills education for children and adolescents in schools. Retrieved from: http://whqlibdoc.who.int/hq/1994/WHO_MNH_PSF_93. 7A_Rev.2.pdf 